\title{
Image Watermarking pada Citra Medis menggunakan Compressive Sensing berbasis Stationary Wavelet Transform
}

\author{
YASQI HAFIZHANA, IRMA SAFITRI, LEDYA NOVAMIZANTI, NUR IBRAHIM \\ Universitas Telkom, Indonesia \\ Email: irmasaf@telkomuniversity.ac.id
}

Received 16 Agustus 2019| Revised 3 September 2019| Accepted 24 September 2019

\begin{abstract}
ABSTRAK
Watermarking pada citra medis dilakukan untuk melindungi hak kepemilikan dan keaslian sebuah citra medis. Proses embedding dan extraction dirancang menggunakan metode Stationary Wavelet Transform (SWT) dan Statistical Mean Manipulation (SMM) untuk mengubah citra host menjadi sinyal sparse kemudian memasuki proses watermarking. Citra watermark dioptimasi dengan menggunakan metode Compressive Sensing (CS). Hasil akhir dari penelitian ini menunjukkan simulasi Image Watermarking dengan Bit Error Rate (BER) mendekati nilai nol dan PSNR lebih besar dari $40 \mathrm{~dB}$, tanpa diberikan serangan. Penerapan Compressive Sensing menyebabkan nilai PSNR meningkat hingga 3,5 $d B$ dan embedding capacity menjadi empat kali lipat lebih baik.
\end{abstract}

Kata Kunci: Image watermarking, Telemedicine, Stationary Wavelet Transform, Statistical Mean Manipulation, Compressive Sensing.

\begin{abstract}
Watermarking in medical images is carried out to protect ownership rights and authenticity of a medical image. The embedding and extraction process was designed using Stationary wavelet transform (SWT) and Statistical Mean Manipulation (SMM) methods to convert the host image into a sparse signal and then enter the watermarking process. The watermark image is optimized using the Compressive Sensing (CS) method. The final result of this final project shows the simulation of Image Watermarking with the Bit Error Rate (BER) approaching zero and PSNR greater than $40 \mathrm{~dB}$, without being given an attack. The application of the Compressive Sensing pursuit will cause the PSNR increase up to $3.5 d B$ and embedding capacity four times better.
\end{abstract}

Keywords: Image watermarking, Telemedicine, Stationary Wavelet Transform, Statistical Mean Manipulation, Compressive Sensing. 


\section{PENDAHULUAN}

Telemedicine merupakan istilah untuk penggunaan teknologi informasi pada dunia medis. Penggunaan teknologi informasi dalam bidang medis memberikan kemudahan dalam melakukan penanganan medis, namun kemudahan tersebut dapat menjadi ancaman keamanan karena mudahnya manipulasi dan replikasi. Dalam penggunaan EPR (Electronic Patient Record) membutuhkan validasi yaitu keaslian dan kepemilikan informasi medis tersebut (Zain \& Clarke, 2005). Teknik watermarking dapat diterapkankan sebagai langkah untuk melindungi keaslian dan kepemilikan suatu informasi data digital.

Pada penelitian ini diterapkan metode Stationary Wavelet Transform (SWT) dan Statistical Mean Manipulation (SMM). Metode tersebut dipilih karena tidak ditemukan penelitian dengan topik image watermarking mengguna kombinasi kedua metode tersebut. Pemilihan metode SWT merujuk kepada beberapa penelitian. Pada penelitian (Zhang dkk, 2010) menyatakan bahwa Metode SWT lebih baik dibandingkan metode Discrete Wavelet Transform (DWT) dalam hal translation invariant property. Berdasarkan penelitian (Purohit dkk, 2017) dapat diketahui bahwa, pada image watermarking, metode SWT menunjukkan peningkatan pada nilai Peak Signal to Noise Ratio (PSNR) dan citra watermark yang ter-extraction sangat berkorelasi dengan watermark aslinya untuk berbagai serangan. Kemudian penelitian (Kumar \& Ramashri, 2012) menyatakan pada kesimpulannya bahwa penggunaan metode SWT membantu meningkatkan kapasitas untuk watermark berukuran besar, dan metode ini dapat diperluas untuk citra berwarna. Pemilihan metode SMM mengacu pada penelitian (Li \& Yu, 2000) yang menyatakan bahwa SMM membuat watermarking lebih tahan terhadap serangan, terutama pada serangan yang merusak struktur sinkronisasi sinyal dalam bentuk audio seperti jittering.

\subsection{Citra Digital}

Citra digital adalah suatu fungsi kontinu intensitas cahaya dalam bentuk matriks $x$ dan $y$ $(f(x, y))$ atau dua dimensi. Pada matriks tersebut simbol $x$ menyatakan jumlah baris pada matriks, dan simbol $y$ menyatakan jumlah kolom pada matriks. Persamaan (1) merupakan matriks citra digital dengan ukuran $[M \times N]$.

$$
f(x, y)=M \times N=\left[\begin{array}{ccc}
(0,0) & \cdots & (0, N-1) \\
\vdots & \ddots & \vdots \\
(M-1,0) & \cdots & (M-1, N-1)
\end{array}\right]
$$

Pada setiap titik koordinat matriks tersebut memiliki nilai bilangan bulat yang merupakan tingkat kedalaman warna (color depth) pada citra digital. Titik-titik pada citra digital tersebut merupakan elemen terkecil pada citra digital yaitu pixel. Suatu citra digital memiliki resolusi atau ukuran suatu citra digital yang sesuai dengan banyaknya jumlah pixel.

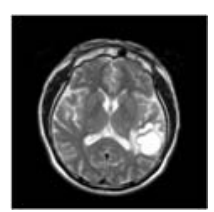

\section{Gambar 1. Contoh Citra Medis (Jones, 2013)}

Gambar 1 menunjukkan contoh citra medis. Citra medis adalah salah satu penerapan teknologi citra digital dalam bidang medis. Citra medis merupakan hasil dari teknik perekaman pada beberapa bagian organ tubuh manusia menggunakan teknologi alat perekam medis dengan 
tujuan tertentu. Citra medis menjadi alat pendukung dalam penanganan medis terhadap pasien (Zain \& Clarke, 2005).

\subsection{Watermarking}

Watermarking merupakan proses penyisipan informasi terhadap suatu data digital (host) seperti teks, suara, gambar/citra (image), dan gambar bergerak (video). Informasi yang disisipkan merupakan suatu tanda rahasia yang tidak kasat mata. Pada watermarking, informasi rahasia diharapkan tidak dapat direkonstruksi atau dilihat oleh siapa pun, terkecuali orang yang berwenang (Cox dkk, 2008).

\subsection{Compressive Sensing}

Compressive Sensing (CS) merupakan suatu metode kompresi dan rekonstruksi pada suatu sinyal atau citra tertentu dengan jumlah sempel yang sedikit. CS mengambil sempel (dalam mode independen sinyal) pada tingkat rendah, kemudian menggunakan daya komputasi untuk rekonstruksi yang terdeteksi sebagai rangkaian pengukuran yang tidak lengkap (Candes \& Wakin, 2008). Dalam proses rekonstruksi matriks citra digital, terdapat transformasi yang menjadi alur dalam sistem CS yaitu Sparsity Transform (Transformasi penjarang- $\psi$ ) dan Projection Transform (Transformasi proyeksi- $\phi$ ).

CS dapat merekonstruksi sinyal dengan menggunakan sejumlah pengukuran acak yang disebut sensing matrix dan sinyal dalam bentuk sparse. Citra sparse mengandung beberapa koefisien sebagai non-zero dan koefisien lainnya adalah zero (Pangestu, 2017). CS secara umum dapat digunakan dalam proses watermarking. CS dapat diimplementasikan dalam tiga algoritma proses watermarking, yaitu:

\section{Encoder}

Dalam proses ini, watermark $v$ disisipkan pada CS Measurement dari sinyal sparse $x$. Citra watermarking sendiri direpresentasikan dengan Persamaan (2),

$$
y_{v}=\emptyset x+D v
$$

dimana $D$ adalah matriks acak dengan ukuran $M \times L$ dan itu harus diketahui sebelum memulai prosedur embedding dan extraction (Bash \& Kayhan, 2015).

\section{Algoritma Rekonstruksi}

Orthogonal Matching Pursuit merupakan greedy algorithm hasil pengembangan dari Matching Pursuit (MP). OMP memprediksi besaran koefisien non-zero dari $x$ dengan menyelesaikan kesalahan pada kuadrat terkecil antara proyeksi orthogonal dari $x$ yang sudah dikembalikan dan perhitungan vektor $y$ (Bash \& Kayhan, 2015). Perhitungan dari CS watermarking $y_{v}$ termasuk $k$-sparse $x$ dan $L$ bit citra yang sudah diberikan watermarking $v$, kemudian $y_{v}$ direkonstruksi menggunakan algoritma OMP dari $y_{v}$ yang dihitung dengan Persamaan (3),

$$
\hat{x}=\arg \min _{x}\|y-\phi x\|_{2}
$$

diubah menjadi Persamaan (4),

$$
\hat{z}=\arg \min _{x}\left\|y_{v}-H Z\right\|_{2}
$$

dimana $\hat{z}=\left[\frac{\tilde{x}}{\tilde{v}}\right]$ dan $z=\left[\frac{x}{v}\right]$ (Bash \& Kayhan, 2015).

\section{Decoder}

Decoder dalam proses extraction citra watermarking. Setelah rekonstruksi melalui CS measurements watermarking, decoder digunakan untuk mengekstrak watermark dengan Persamaan (5) sampai dengan Persamaan (7),

$$
\text { ELKOMIKA - } 45
$$




$$
\begin{gathered}
\hat{z}=\arg \min _{x}\left\|y_{v}-H Z\right\|_{2} \\
\hat{v}=\alpha * \operatorname{sgn}(\tilde{v}) \\
\hat{x}=\arg \min _{x}\left\|\left(y_{v}-D \hat{v}\right)-\phi x\right\|_{2}
\end{gathered}
$$

dimana $\hat{x}$ adalah citra yang dipulihkan dan $\hat{v}$ adalah citra watermark yang sudah diekstraksi (Bash \& Kayhan, 2015).

\subsection{Stationary Wavelet Transform (SWT)}

Stationary Wavelet Transformation (SWT) memiliki sistem kerja atau algoritma yang hampir sama dengan Discrete Wavelet Transformation (DWT). Meskipun terdapat pada domain yang sama, namun pada SWT tidak dilakukan downsampling pada setiap step dekomposisinya. Oleh karena itu SWT memiki nama lain Undecimated Wavelet Transformation (undecimated sendiri memiliki makna tidak dilakukannya downsampling). Transformasi wavelet sendiri, berfungsi untuk memperlebar sinyal digital ke dalam bentuk domain wavelet. Proses ini bertujuan untuk mendapatkan informasi yang tidak muncul pada domain aslinya (umumnya waktu) (Ward, 2018). Dekomposisi dilakukan untuk mendapatkan sinyal pada frekuensi tinggi dan rendah dengan cara melewatkan sinyal informasi ke High Pass Filter (HPF) (G(z)), dan Low Pass Filter (LPF) $(H(z))$. Pembeda antara SWT dengan DWT terdapat pada operator downsampling yang tidak digunakan pada SWT. Perbedaan tersebut dapat dilihat pada Gambar 2 diagram proses DWT dan Gambar 3 diagram proses SWT.

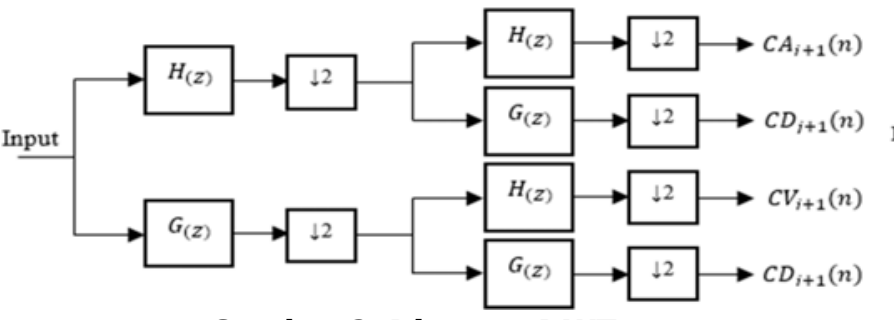

Gambar 2. Diagram DWT

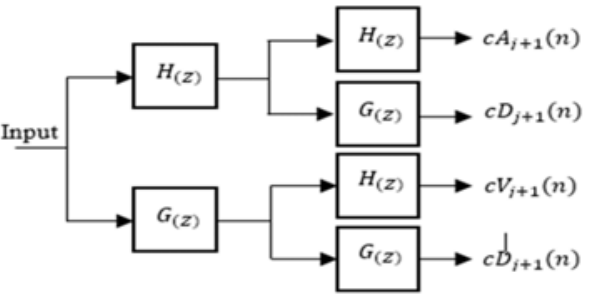

Gambar 3. Diagram SWT

Downsampling sendiri menghilangkan koefisien redundant, yang sebenarnya tidak diperlukan untuk merekonstruksi sinyal secara sempurna (Ward, 2018). Pada DWT, koefisien upsampling (Bash \& Kayhan, 2015) dan downsampling ada pada setiap proses dekomposisi. Karena hal ini pula, metode SWT lebih tangguh dibandingkan metode DWT (Zhang dkk, 2010).

\subsection{Statistical Mean Manipulation (SMM)}

Statistical Mean Manipulation (SMM) merupakan salah satu metode penyisipan pada lingkup watermarking yang menggunakan pengolahan statistik sebagai teknik penyisipan dengan pengambilan nilai rata-rata terhadap sejumlah bilangan tertentu. Dengan menggunakan metode ini, nilai rata-rata pada matriks sinyal input tertentu dapat diatur secara statistik. Pada bilangan yang telah diolah secara statistik, watermark image mewakili masing-masing bit " 0 " dan bit "1" pada susunan nilai rata-rata. Formula untuk teknik penyisipan, pada bit "1" ditunjukkan oleh Persamaan (8) dan pada bit "0" ditunjukkan oleh persamaan (9),

$$
\begin{aligned}
& x_{c w}(n)=x_{c}(n)-\mu x+\alpha \\
& x_{c w}(n)=x_{c}(n)-\mu x-\alpha
\end{aligned}
$$


dimana, $x_{c}(n)$ adalah sinyal dalam domain cepstrum, $\mu_{i}$ adalah rata-rata sinyal $x_{c}(n), \alpha$ adalah faktor manipulasi rata-rata pada SMM yang dapat memastikan keandalan dari penyisipan ini, dan $x_{c w}(n)$ adalah image yang telah ter-watermark. Kekuatan penyisipan watermark dikendalikan oleh $a$. koefisien $\mu$ pada watermark dapat dideteksi dengan menghitung dan membandingkan ambang batas yang telah ditetapkan. Hal ini dikarenakan koefisien $\mu$ memiliki nilai pada kisaran $10^{-4}$ yang cukup kecil untuk perbandingan tersebut (Wen dkk, 2009).

\section{PEMODELAN SISTEM}

Pada penelitian ini dilakukan perancangan sistem image watermarking pada citra medis dengan menggunakan metode Stationary Wavelet Transfornsm (SWT) dan teknik penyisipan Statistical Mean Manipulation (SMM) dengan Compressive Sensing (CS) algoritma Orthogonal Matching Pursuit (OMP). Gambar 4 menunjukkan skema model sistem yang digunakan pada penelitian ini.

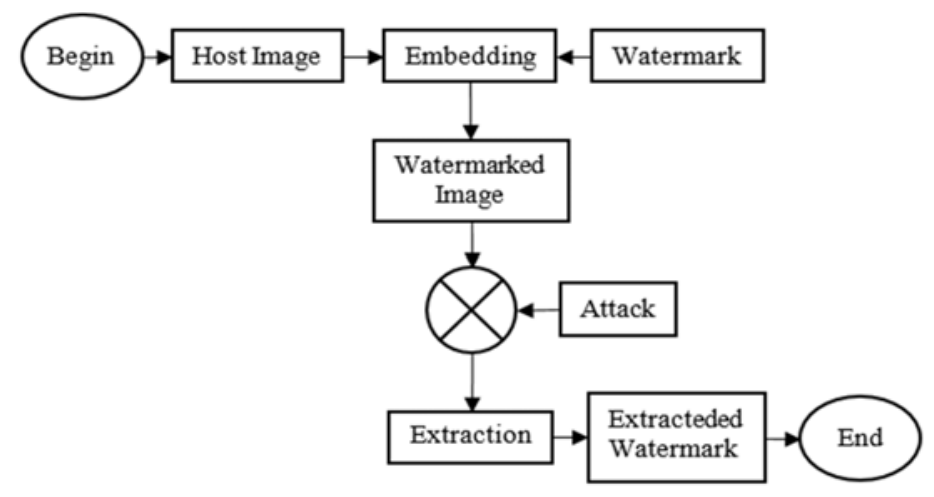

Gambar 4. Bagan Model Perancangan Simulasi Watermarking

Proses implementasi image watermarking pada sebuah citra digital secara umum terbagi kedalam dua proses, penyisipan (embedding) dan pemulihan atau ekstraksi (extraction). Pada proses embedding, dilakukan penyisipan watermark image terhadap host (berupa data citra) hingga didapatkan keluaran Watermarked Image. Pada proses extraction, dilakukan pemulihan atau ekstraksi terhadap watermarked image untuk dapat merekonstruksi watermark image kembali. Setelah proses embedding, dilakukan serangan terhadap watermarked image untuk menguji kualitas dan ketahanan sistem watermarking (robustness).

\subsection{Perancangan Watermarking Tanpa Compessive Sensing}

1. Embedding

Bagan dan tahapan-tahapan pada proses embedding ditunjukkan pada Gambar 5,

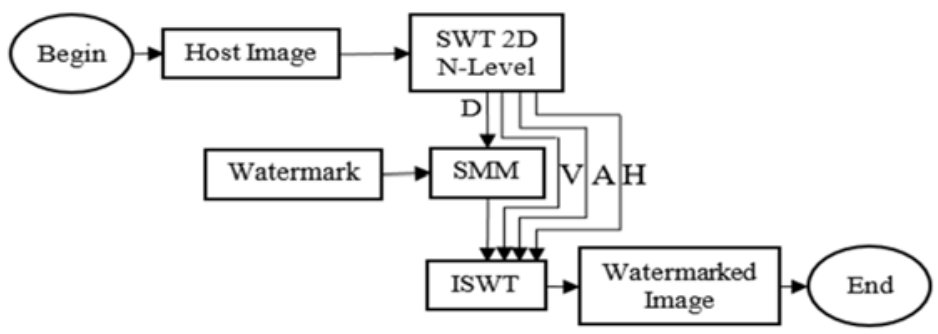

Gambar 5. Bagan Tahap Embedding Tanpa Compressive Sensing

ELKOMIKA - 47 
1) Tahap pertama pada proses embedding adalah pemilihan host dan watermark image. Host yang dipilih merupakan citra medis digital RGB 16bit dalam format *.bmp dengan resolusi $256 \times 256,512 \times 512,1024 \times 1024,2048 \times 2048$ pixel. Watermark image yang digunakan adalah citra biner dalam format *.bmp dengan resolusi $16 \times 16$.

2) Dilakukan proses segmentasi pada setiap layer host untuk mempermudah proses embedding. Dapat dilihat pada Gambar 6, ilustrasi tersebut merupakan proses segmentasi pada host gambar dengan resolusi $4 \times 4$ pixe/yang disisipkan watermark dengan resolusi $2 \times 2$ pixel.

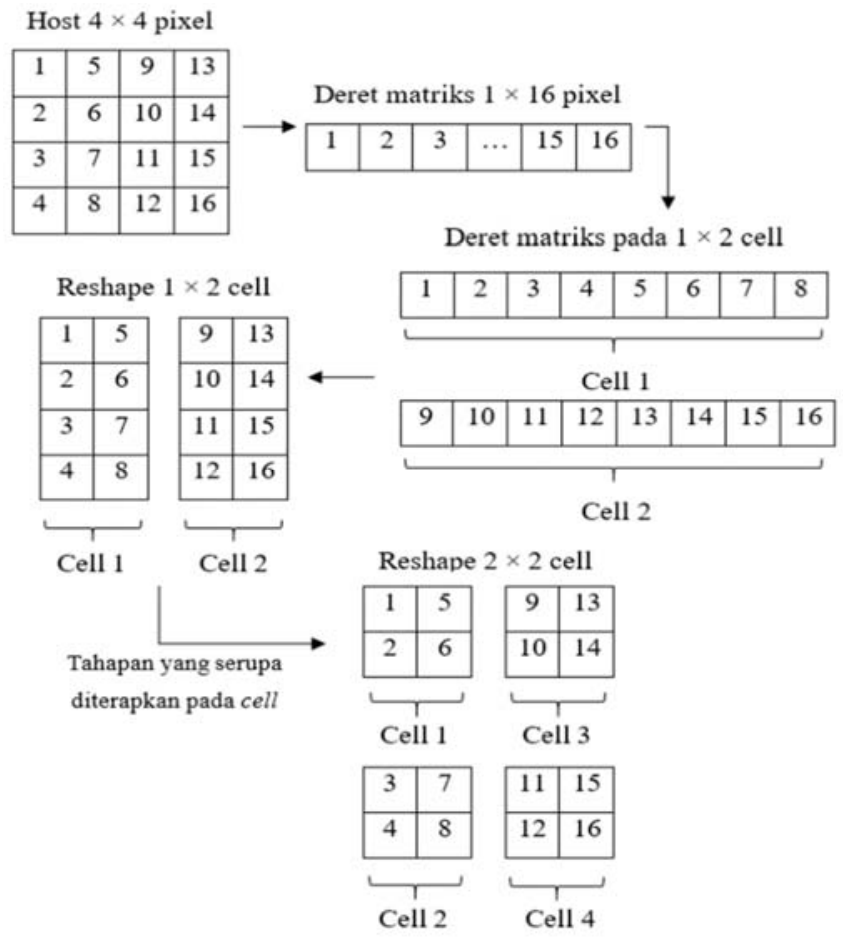

Gambar 6. Ilustrasi Proses Segmentasi

3) Tahap berikutnya dilakukan filtering terhadap host menggunakan Stationary Wavelet Transform (SWT) pada level tertentu untuk mengubah host kedalam bentuk sparse. Pada SWT 2 dimensi N-level, dilakukan filter terhadap sempel dengan menggunakan dua filter yaitu Low Pass Filter (LPF) $\left(H_{(z)}\right)$ dan High Pass Filter (HPF) $\left(G_{(z)}\right)$. Pada penelitian ini dipilih keluaran filter LPF SWT 2D dengan leve/ 3 yaitu matriks diagonal (D) sebagai sempel yang disisipkan watermark image.

4) Tahap berikutnya adalah penyisipan watermark pada hasil filtering. Watermark image yang dipilih adalah citra biner dengan format *.bmp. Watermark image disisipkan pada matriks diagonal hasil dari proses SWT 2 dimensi leve/3 menggunakan metode Statistical Mean Manipulation (SMM).

5) Sesuai dengan Gambar 4, sempel yang telah disisipkan watermark digabungkan kembali dengan sempel lainnya menggunakan metode rekonstruksi Inverse Stationary Wavelet Transform (ISWT) untuk mendapatkan watermarked image.

2. Extraction

Proses extraction digambarkan sesuai dengan bagan pada Gambar 7. 


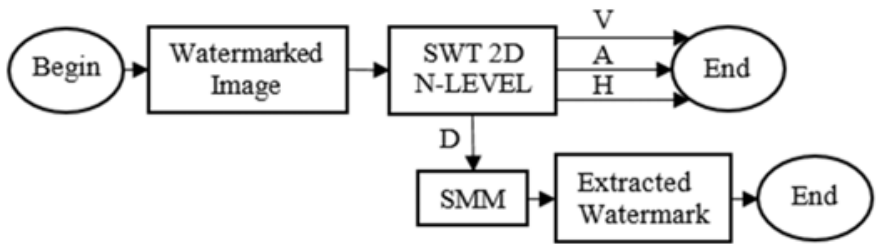

Gambar 7. Bagan Tahap Extraction Tanpa Compressive Sensing

Tahap pelaksanaan dijelaskan dalam urutan berikut ini:

1) Dilakukan proses segmentasi pada setiap layer host seperti pada proses embedding. Ilustrasi proses segmentasi dapat dilihat pada pada Gambar 7.

2) Watermarked image diubah kedalam bentuk sparse dengan menggunakan metode dekomposisi SWT 2 dimensi $N$-level. Pada proses ini digunakan SWT 2 dimensi leve/ 3 (sesuai dengan SWT 2 dimensi $\mathrm{N}$-leve/pada proses embedding). Dalam proses extraction, digunakan sempel matriks diagonal (D), karena penyisipan pada proses embedding dilakukan pada matriks diagonal(D).

3) Kemudian sempel tersebut melalui proses pemulihan watermark atau rekonstruksi watermark dengan menggunakan metode SMM.

4) Hasil akhir dari proses extraction berupa watermark image.

\subsection{Perancangan Watermarking Dengan Compessive Sensing}

1. Embedding

Gambar 8 merupakan bagan dan tahap-tahap pada proses embedding dengan compressive sensing,

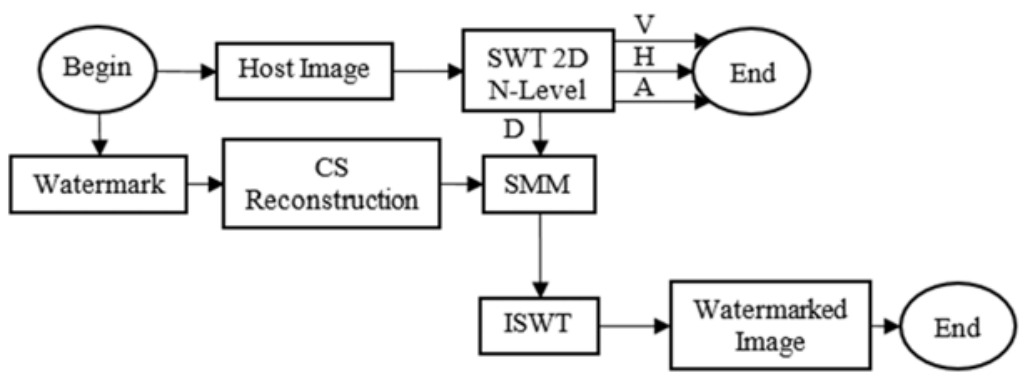

Gambar 8. Bagan Tahap Embedding Dengan Compressive Sensing

Seperti yang dapat dilihat pada Gambar 8, tidak terdapat banyak perbedaan dengan proses embedding tanpa CS. Perbedaan hanya terdapat pada pengolahan watermark image. Sebelum disisipkan pada host, watermark image diolah terlebih dahulu melalui proses compressive sensing reconstruction. Compressive sensing reconstruction mengubah matriks pada watermark image ke dalam bentuk sparse. Hasil dari proses tersebut kemudian di sisipkan kedalam host menggunakan metode Statistical Mean Manipulation (SMM).

\section{Extraction}

Pada Gambar 9 ditunjukkan proses extraction dengan compressive sensing. Pada proses extraction ini, setelah dilakukan proses pemulihan pada watermark dengan metode SMM, watermark image dikompresi dengan compressive sensing reconstruction. 


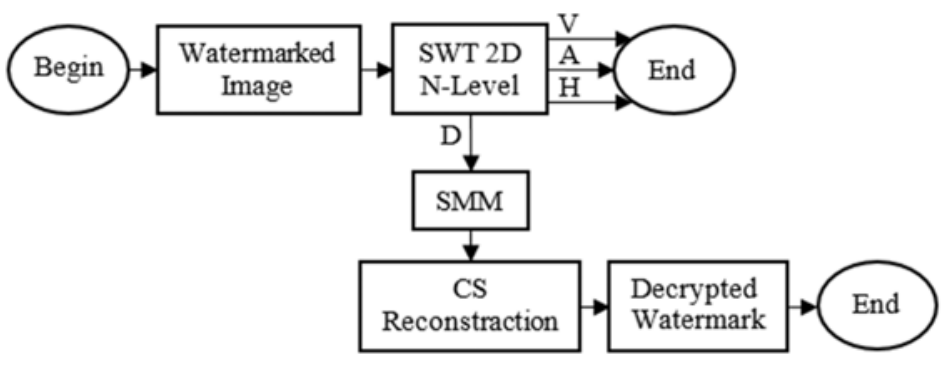

Gambar 9. Bagan Tahap Extraction Dengan Compressive Sensing

\subsection{Analisis Kualitas Watermarking}

Proses berikut ini dilakukan untuk memenuhi tujuan penelitian ini yaitu mengetahui kualitas sistem watermarking yang dirancang. Parameter kualitas watermarking yang diperhatikan adalah robustness, transparency, dan embedding capacity. Tingkat robustness pada watermarking dapat dianalisis melalui nilai BER dengan membandingkan antara watermark setelah proses extraction dan watermark sebelum proses embedding. Analisis pada robustness dilakukan dengan atau tanpa serangan. Serangan pada watermarking yang diterapkan pada penelitian ini adalah rotate, scaling, cropping, filtering, noise dan Joint Photographic Experts Group (JPEG) compression. Tingkat transparency pada watermarking dapat dianalisis melalui nilai PSNR dan MOS dengan membandingkan antara host (citra asli) dengan watermarked image dalam proses embedding. Embedding capacity dapat dianalisis melalui penyebaran bit watermark di dalam host pada proses embedding. Tingkat kualitas watermark yang terekstraksi dapat dianalisis melalui nilai BER dan SSIM dengan membandingkan antara watermark asli dengan watermark setelah proses pengolahan atau transmisi. Gambar 10 menunjukkan bagan dari tahap analisis kualitas watermarking penelitian ini.

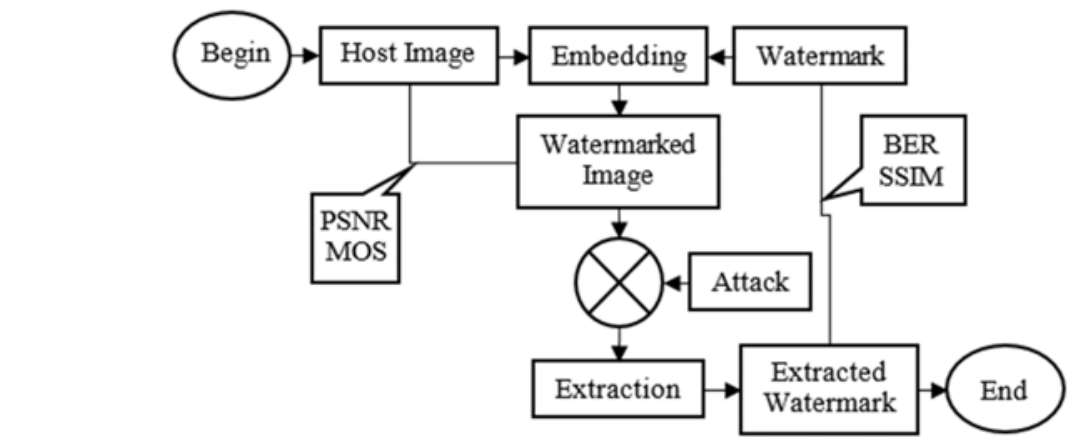

Gambar 10. Bagan Analisis Kualitas Perancangan Simulasi Watermarking

\section{PENGUJIAN DAN ANALISIS DATA}

\subsection{Skenario Pengujian Sistem Image Watermarkings}

Pengujian dilakukan dalam dua bagian, yaitu pengujian terhadap proses embedding dan pengujian terhadap proses extraction. Pengujian terhadap proses embedding pada sistem image watermarking dilakukan untuk mengetahui nilai PSNR, MOS, transparency dan embedding capacity berdasarkan perubahan pada nilai parameter proses embedding. Parameter pengujian proses embedding dapat dilihat pada Tabel 1. 
Tabel 1. Parameter Pengujian Proses Embedding

\begin{tabular}{|c|c|c|c|c|c|}
\hline Parameter & \multicolumn{5}{|c|}{ Variasi Nilai Parameter } \\
\hline Resolusi Citra Host & $256 \times 256$ & $512 \times 512$ & $1.024 \times 1.024$ & $2.048 \times 2.048$ & \\
\hline Faktor Sisip & 0,1 & 0,3 & 0,5 & 0,7 & 0,9 \\
\hline Alfa & 0,01 & 0,03 & 0,05 & 0,07 & 0,09 \\
\hline $\begin{array}{c}\text { Rasio Kompresi Pada } \\
\text { CS }\end{array}$ & $20 \%$ & $40 \%$ & $60 \%$ & & \\
\hline
\end{tabular}

Pengujian pada proses extraction sistem image watermarking dilakukan untuk menganalisis ketahanan watermark setelah dilakukan penyisipan melalui proses embedding. Pengujian pada proses extraction dilakukan dengan atau tanpa serangan terhadap watermarked image. Parameter pengujian serangan dapat dilihat pada Tabel 2.

Tabel 2. Parameter Serangan pada Proses Extraction

\begin{tabular}{|c|c|c|c|c|}
\hline Jenis Serangan & \multicolumn{4}{|c|}{ Index Serangan } \\
\hline JPEG Compression & $25 \%$ & $50 \%$ & $75 \%$ & $100 \%$ \\
\hline Rotating & $90^{\circ}$ & $180^{\circ}$ & $270^{\circ}$ \\
\hline Scaling & \multicolumn{2}{|c|}{$50 \%$} & $150 \%$ \\
\hline Cropping & \multicolumn{3}{|c|}{8 pixel } & 16 pixel \\
\hline Filtering & \multicolumn{3}{|c|}{ Median } \\
\hline Additive White Gaussian Noise (AWGN) & 0,001 & 0,01 & 0,1 \\
\hline Salt and Pepper Noise & 0,001 & 0,01 & 0,1 \\
\hline
\end{tabular}

\subsection{Pengaruh Perubahan Parameter-Parameter pada Image Watermarking} 3.2.1 Pengaruh Perubahan Resolusi Host

Hasil pengujian pengaruh resolusi host dapat dilihat pada Tabel 3.

Tabel 3. Hasil Pengujian Pengaruh Resolusi Host

\begin{tabular}{|c|c|c|c|c|}
\hline \multirow{2}{*}{ Resolusi Host } & \multicolumn{4}{|c|}{ Faktor Sisip = 0,9, Alfa = 0,01, Tanpa CS } \\
\cline { 2 - 5 } & BER & SSIM & PSNR & Capacity \\
\hline $256 \times 256$ & 0,035156 & 0,921782 & 53,67941 & 256 \\
\hline $512 \times 512$ & 0,09375 & 0,794242 & 56,03058 & 1024 \\
\hline $1.024 \times 1.024$ & 0,113281 & 0,755206 & 61,04405 & 4096 \\
\hline $2.048 \times 2.048$ & 0,085938 & 0,801745 & 64,7776 & 16384 \\
\hline
\end{tabular}

Berdasarkan Tabel 3, dapat diamati bahwa semakin besar resolusi host maka semakin besar pula nilai PSNR dan embedding capacity. Hal tersebut dapat terjadi karena cakupan wilayah yang dapat disisipkan watermark semakin besar sesuai dengan banyaknya pixe/ pada citra host. Sedangkan nilai BER dan SSIM mengalami fluktuasi dengan trendyang menurun, karena jumlah pixel yang banyak pada proses penyisipan memperbesar kemungkinan terjadinya perubahan pada nilai pixe/ pada host secara masif dan menyebabkan kesalahan pada proses extraction atau pemulihan citra watermark.

\subsubsection{Pengaruh Nilai Faktor Sisip}

Pada proses penyisipan watermark, dibutuhkan suatu nilai yang menentukan banyaknya bagian bilangan pada suatu matriks yang hendak disisipkan watermark. Faktor sisip dengan nilai 1 pada pengujian menunjukan bahwa seluruh bilangan pada bagian matriks D dilakukan penyisipan watermark. Hasil pengujian pengaruh nilai faktor sisip dapat dilihat pada Tabel 4. 
Tabel 4. Hasil Pengujian Pengaruh Nilai Faktor Sisip

\begin{tabular}{|c|c|c|c|c|}
\hline \multirow{2}{*}{ Faktor Sisip } & \multicolumn{4}{|c|}{ Resolusi Host $\mathbf{2 5 6} \times \mathbf{2 5 6}$, Alfa = 0,01, Tanpa CS } \\
\cline { 2 - 5 } & BER & SSIM & PSNR & Capacity \\
\hline 0,1 & 0,125 & 0,729237 & 66,45033 & 256 \\
\hline 0,3 & 0,058594 & 0,86509 & 60,09633 & 256 \\
\hline 0,5 & 0,066406 & 0,853764 & 56,62621 & 256 \\
\hline 0.7 & 0,085938 & 0,810302 & 54,98198 & 256 \\
\hline 0,9 & 0,035156 & 0,921782 & 53,67941 & 256 \\
\hline
\end{tabular}

Semakin tinggi nilai faktor sisip maka semakin rendah nilai PSNR, karena semakin banyaknya pixe/yang terlibat pada penyisipan tiap bit watermarkmenyebabkan besarnya perubahan nilai matriks pada citra host. Tetapi, semakin besar nilai faktor sisip semakin baik nilai BER dan SSIM, karena semakin besarnya nilai faktor sisip menyebabkan banyaknya bilangan pada matriks host yang dapat disisipkan tiap bit watermark.

\subsubsection{Pengaruh Nilai Alfa}

Pada metode penyisipan statistical mean manipulation, nilai alfa menentukan kekuatan penyisipan watermark terhadap host. Hasil pengujian pada Tabel 5 menunjukkan bahwa semakin kecil nilai alfa pada pengujian semakin besar nilai PSNR yang didapatkan. Salah satu penyebabnya antara lain nilai alfa (pada range pengujian) hanya mempengaruhi watermark pada proses penyisipan, dimana semakin kecil nilai alfa maka semakin baik bit citra watermark yang disisipkan.

Tabel 5. Hasil Pengujian Pengaruh Nilai Alfa

\begin{tabular}{|c|c|c|c|c|}
\hline \multirow{2}{*}{ Alfa } & \multicolumn{4}{|c|}{ Resolusi $\boldsymbol{H o s t} \mathbf{2 5 6} \times \mathbf{2 5 6}, \mathbf{F a k t o r ~ S i s i p ~ = ~} \mathbf{0 , 9}$, Tanpa CS } \\
\cline { 2 - 5 } & BER & SSIM & PSNR & Capacity \\
\hline 0,01 & 0,035156 & 0,921782 & 53,67941 & 256 \\
\hline 0.03 & 0,035156 & 0,921782 & 50,21527 & 256 \\
\hline 0,05 & 0,035156 & 0,921782 & 46,48018 & 256 \\
\hline 0.07 & 0,035156 & 0,921782 & 44,25782 & 256 \\
\hline 0,09 & 0,035156 & 0,921782 & 41,80584 & 256 \\
\hline
\end{tabular}

\subsection{Analisis Pengaruh Compressive Sensing pada Watermark}

Compressive Sensing (CS) dengan algoritma Orthogonal Matching Pursuit (OMP) diimplementasikan pada penelitian ini. Penggunaan CS algoritma OMP dilakukan pada citra watermark yang disisipkan pada proses watermarking. Dalam pengamatan ini dilakukan kompresi dengan hasil keluaran berdimensi $16 \times 16$ pixe/ dan $8 \times 8$ pixel. Rasio kompresi yang digunakan adalah $20 \%$, $40 \%$ dan $60 \%$.

\subsubsection{Analisis Pengaruh Resolusi Kompresi Compressive Sensing}

Resolusi kompresi merupakan dimensi yang digunakan sebagai hasil dari proses kompresi. Hasil pengujian pengaruh resolusi compressive sensing ditunjukkan pada Tabel 6 .

Tabel 6. Hasil Pengujian Pengaruh Resolusi Compressive Sensing

\begin{tabular}{|c|c|c|c|c|c|}
\hline \multirow{2}{*}{ Pixel } & \multicolumn{5}{|c|}{ Resolusi Host $=\mathbf{2 5 6} \times \mathbf{2 5 6}$, Faktor Sisip $=\mathbf{0 , 9}$, Alfa = 0,01 } \\
\cline { 2 - 6 } & BER & SSIM & PSNR & Capacity & Ket. \\
\hline $16 \times 16$ & 0,035156 & 0,921782 & 53,67941 & 256 & Tanpa CS \\
\hline $16 \times 16$ & 0,125 & 0,678145 & 53,73613 & 256 & CS $=20 \%$ \\
\hline $8 \times 8$ & 0,3125 & 0,320469 & 56,86462 & 1.024 & CS $=20 \%$ \\
\hline
\end{tabular}


Semakin kecil resolusi kompresi, maka semakin baik nilai PSNR dan embedding capacity-nya. Hal ini terjadi karena semakin kecilnya resolusi watermark yang disisipkan dapat berpengaruh terhadap cakupan penyisipan yang semakin besar setiap bit watermark terhadap citra host.

\subsubsection{Analisis Pengaruh Rasio Kompresi Compressive Sensing}

Rasio kompresi merupakan perbandingan antara data asli dengan data hasil kompresi. Hasil pengujian pengaruh rasio kompresi compressive sensing dapat dilihat pada Tabel 7.

Tabel 7. Hasil Pengujian Pengaruh Rasio Kompresi Compressive Sensing

\begin{tabular}{|c|c|c|c|c|c|}
\hline \multirow{2}{*}{ Pixel } & \multirow{2}{*}{ CS } & \multicolumn{4}{|c|}{ Resolusi Host $\mathbf{2 5 6} \times \mathbf{2 5 6}$, Faktor Sisip = 0,9 , Alfa = 0,01 } \\
\cline { 3 - 6 } & & BER & SSIM & PSNR & Capacity \\
\hline $16 \times 16$ & Tanpa CS & 0,035156 & 0,921782 & 53,67941 & 256 \\
\hline \multirow{3}{*}{$16 \times 16$} & $20 \%$ & 0,125 & 0,678145 & 53,73613 & 256 \\
\cline { 2 - 6 } & $40 \%$ & 0,082031 & 0,786366 & 53,62623 & 256 \\
\cline { 2 - 6 } & $60 \%$ & 0,042969 & 0,90227 & 53,65688 & 256 \\
\hline \multirow{3}{*}{$8 \times 8$} & $20 \%$ & 0,3125 & 0,320469 & 56,86462 & 1.024 \\
\cline { 2 - 6 } & $40 \%$ & 0,234375 & 0,486996 & 56,50376 & 1.024 \\
\cline { 2 - 6 } & $60 \%$ & 0,078125 & 0,82811 & 56,07586 & 1.024 \\
\hline
\end{tabular}

Nilai PSNR dan embedding capacity mencapai nilai optimum pada rasio kompresi $60 \%$ dengan resolusi kompresi $8 \times 8$ pixel. Hasil tersebut dapat disebabkan oleh semakin ringkasnya resolusi citra watermark dan semakin baiknya kualitas kompresi.

\subsection{Analisis Ketahanan Watermark Terhadap Serangan}

\subsubsection{Ketahanan Watermark terhadap Serangan Rotating}

Rotating merupakan proses pengolahan data gambar dengan mengubah sudut gambar pada titik pusat rotasinya. Berdasarkan Tabel 8, dapat diamati bahwa watermark bertahan lebih baik pada serangan putaran $180^{\circ}$ dibandingkan pada serangan $90^{\circ}$ dan $270^{\circ}$. Implementasi CS terhadap citra watermarkmembuat watermark-nya lebih rentan terhadap serangan kecuali pada serangan rotating $90^{\circ}$, dimana terlihat adanya peningkatan ketahanan terhadap serangan. Kemudian, pada penerapan CS rasio $60 \%$, watermark mengalami peningkatan ketahanan terhadap serangan rotating $180^{\circ}$ dengan cukup baik.

Tabel 8. Hasil Pengujian Serangan Rotating

\begin{tabular}{|c|c|c|c|c|c|c|}
\hline Status & Rotating & Value & Tanpa CS & CS 20\% & CS $40 \%$ & CS 60\% \\
\hline \multirow{9}{*}{$\begin{array}{c}\text { Resolusi Host } \\
256 \times 256 \\
\text { Faktor Sisip } \\
0,9 \\
\text { Alfa } \\
0,01\end{array}$} & \multirow{3}{*}{$90^{\circ}$} & BER & 0,429688 & 0,40625 & 0,40625 & 0,40625 \\
\hline & & SSIM & 0,00038 & 0,052669 & 0,052669 & 0,052669 \\
\hline & & PSNR & 53,67941 & 56,86462 & 56,50376 & 56,07586 \\
\hline & \multirow{3}{*}{$180^{\circ}$} & BER & 0,328125 & 0,40625 & 0,375 & 0,265625 \\
\hline & & SSIM & 0,276606 & 0,120553 & 0,226615 & 0,459151 \\
\hline & & PSNR & 53,67941 & 56,86462 & 56,50376 & 56,07586 \\
\hline & \multirow{3}{*}{$270^{\circ}$} & BER & 0,453125 & 0,421875 & 0,421875 & 0,421875 \\
\hline & & SSIM & 0,01 & 0,019925 & 0,019925 & 0,008583 \\
\hline & & PSNR & 53,67941 & 56,86462 & 56,50376 & 56,07586 \\
\hline
\end{tabular}

\subsubsection{Ketahanan Watermark terhadap Serangan Scaling}

Scaling merupakan proses pengolahan gambar dengan memperbesar atau memperkecil suatu gambar. Scaling dapat digunakan untuk memperjelas suatu gambar. Hasil pengujian serangan scaling dapat dilihat pada Tabel 9. 
Tabel 9. Hasil Pengujian Serangan Scaling

\begin{tabular}{|c|c|c|c|c|c|c|}
\hline Status & Scaling & Value & Tanpa CS & CS 20\% & CS $40 \%$ & CS 60\% \\
\hline \multirow{6}{*}{$\begin{array}{c}\text { Resolusi Host } \\
256 \times 256 \\
\text { Faktor Sisip } \\
0,9 \\
\text { Alfa } \\
0,01\end{array}$} & \multirow{3}{*}{$50 \%$} & BER & 0,1875 & 0,359375 & 0,34375 & 0,359375 \\
\hline & & SSIM & 0,586788 & 0,238066 & 0,242807 & 0,195623 \\
\hline & & PSNR & 53,67941 & 56,86462 & 56,50376 & 56,07586 \\
\hline & \multirow{3}{*}{$150 \%$} & BER & 0,082031 & 0,359375 & 0,25 & 0,140625 \\
\hline & & SSIM & 0,82555 & 0,252919 & 0,475458 & 0,697066 \\
\hline & & PSNR & 53,67941 & 56,86462 & 56,50376 & 56,07586 \\
\hline
\end{tabular}

Informasi pada Tabel 9 menunjukkan bahwa citra watermark dapat bertahan pada serangan scaling dengan cukup baik, tetapi watermark dapat bertahan lebih baik pada serangan scaling $150 \%$ atau pembesaran. Penerapan CS terhadap citra watermark membuat watermark-nya lebih rentan terhadap serangan scaling, diperbesar maupun diperkecil.

\subsubsection{Ketahanan Watermark terhadap Serangan Cropping}

Cropping adalah proses memotong suatu gambar. Proses pemotongan gambar dilakukan dengan cara menghilangkan atau menghapus pixe/yang tidak diinginkan pada gambar.

Berdasarkan Tabel 10, dapat diamati bahwa watermark tidak dapat bertahan pada serangan cropping. Penerapan CS dengan rasio $20 \%$ membuat watermark tidak lebih tahan terhadap serangan cropping. Namun, pada penerapan CS rasio $40 \%$ dan $60 \%$, watermark dapat bertahan dengan cukup baik terhadap serangan cropping.

Tabel 10. Hasil Pengujian Serangan Cropping

\begin{tabular}{|c|c|c|c|c|c|c|}
\hline Status & Cropping & Value & Tanpa CS & CS 20\% & CS 40\% & CS 60\% \\
\hline Resolusi Host & \multirow{3}{*}{$\begin{array}{c}\text { 256 } \times 256 \\
\text { Faktor Sisip } \\
0,9\end{array}$} & BER & 0,410156 & 0,375 & 0,203125 & 0,15625 \\
\cline { 3 - 7 } & & SSIM & 0,083335 & 0,102768 & 0,541105 & 0,631612 \\
\cline { 3 - 7 } Alfa & \multirow{3}{*}{16 pixel } & PSNR & 53,67941 & 56,86462 & 56,50376 & 56,07586 \\
\cline { 3 - 7 } 0,01 & & BER & 0,390625 & 0,40625 & 0,234375 & 0,15625 \\
\cline { 3 - 7 } & & SSIM & 0,114204 & 0,090058 & 0,463934 & 0,641437 \\
\cline { 3 - 7 } & PSNR & 53,67941 & 56,86462 & 56,50376 & 56,07586 \\
\hline
\end{tabular}

\subsubsection{Ketahanan Watermark terhadap Serangan Filtering}

Filtering adalah proses menghilangkan komponen yang tidak diinginkan pada suatu sinyal. Hasil pengujian serangan filtering dapat dilihat pada Tabel 11.

Tabel 11. Hasil Pengujian Serangan Filtering

\begin{tabular}{|c|c|c|c|c|c|c|}
\hline Status & Filtering & Value & Tanpa CS & CS 20\% & CS 40\% & CS 60\% \\
\hline $\begin{array}{c}\text { Resolusi Host } \\
256 \times 256\end{array}$ & & BER & 0,371094 & 0,34375 & 0,28125 & 0,171875 \\
\cline { 3 - 6 } $\begin{array}{c}\text { Faktor Sisip } \\
0,9\end{array}$ \\
$\begin{array}{c}\text { Alfa } \\
0,01\end{array}$ & Median & SSIM & 0,104045 & 0,192003 & 0,352311 & 0,607026 \\
\cline { 3 - 6 } & & PSNR & 53,67941 & 56,86462 & 56,50376 & 56,07586 \\
\hline
\end{tabular}

Berdasarkan Tabel 11, watermark tidak dapat bertahan terhadap serangan filtering. Penggunaan CS pada watermark menyebabkan watermark lebih tahan terhadap serangan filtering. Pada penerapan CS rasio 60\%, watermark dapat bertahan dengan cukup baik terhadap serangan filtering. 


\subsubsection{Ketahanan Watermark terhadap Serangan Adding Noise}

1. Additive White Gausian Noise (AWGN)

Additive white gausian noise merupakan model noise yang kerap muncul pada berbagai jenis informasi. Noise ini terdistribusi normal dengan nilai yang seragam pada setiap pita frekuensinya. Hasil pengujian serangan adjective white gausian noise dapat dilihat pada Tabel 12.

Berdasarkan Tabel 12, watermark tidak dapat bertahan pada serangan penambahan noise AWGN. Penerapan CS menyebabkan peningkatan ketahanan watermark terhadap serangan AWGN. Pada penerapan CS rasio 60\%, watermark dapat bertahan cukup baik terhadap serangan AWGN.

Tabel 12. Hasil Pengujian Serangan Additive White Gausian Noise

\begin{tabular}{|c|c|c|c|c|c|c|}
\hline Status & $\begin{array}{c}\text { Additive White Gausian } \\
\text { Noise }\end{array}$ & Value & $\begin{array}{c}\text { Tanpa } \\
\text { CS }\end{array}$ & CS 20\% & CS 40\% & CS 60\% \\
\hline \multirow{2}{*}{$\begin{array}{c}\text { Resolusi } \\
\text { Host }\end{array}$} & \multirow{2}{*}{$\begin{array}{c}256 \times 256 \\
\text { Faktor } \\
\text { Sisip } \\
0,9\end{array}$} & BER & 0,296875 & 0,4375 & 0,28125 & 0,15625 \\
\cline { 3 - 7 } $\begin{array}{c}\text { Alfa } \\
0,01\end{array}$ & & SSIM & 0,355287 & 0,10872 & 0,383996 & 0,659786 \\
\cline { 3 - 7 } & \multirow{2}{*}{0,01} & PSNR & 53,67941 & 56,86462 & 56,50376 & 56,07586 \\
\cline { 3 - 7 } & & BER & 0,355469 & 0,390625 & 0,28125 & 0,140625 \\
\cline { 3 - 7 } & & SSIM & 0,22947 & 0,155403 & 0,399185 & 0,69475 \\
\cline { 3 - 7 } & \multirow{2}{*}{0,1} & PSNR & 53,67941 & 56,86462 & 56,50376 & 56,07586 \\
\cline { 3 - 7 } & & SER & 0,5 & 0,46875 & 0,296875 & 0,125 \\
\cline { 3 - 7 } & & SSIM & 0,036881 & 0,039074 & 0,390328 & 0,724969 \\
\cline { 3 - 7 } & & PSNR & 53,67941 & 56,86462 & 56,50376 & 56,07586 \\
\hline
\end{tabular}

2. Salt and Pepper Noise

Salt and pepper noise merupakan bentuk noise yang banyak muncul ditemukan pada gambar. Hasil pengujian serangan salt and papper noise dapat dilihat pada Tabel 13.

Tabel 13. Hasil Pengujian Serangan Salt and Pepper Noise

\begin{tabular}{|c|c|c|c|c|c|c|}
\hline Status & Salt and Pepper Noise & Value & Tanpa CS & CS 20\% & CS 40\% & CS 60\% \\
\hline \multirow{3}{*}{$\begin{array}{c}\text { Resolusi } \\
\text { Host }\end{array}$} & \multirow{2}{*}{$\begin{array}{c}256 \times 0 \\
256\end{array}$} & BER & 0,039063 & 0,3125 & 0,265625 & 0,125 \\
\cline { 3 - 7 } & & SSIM & 0,912869 & 0,320469 & 0,429574 & 0,733842 \\
\cline { 3 - 7 } Faktor & & PSNR & 53,67941 & 56,86462 & 56,50376 & 56,07586 \\
Sisip & \multirow{3}{*}{0,01} & BER & 0,0625 & 0,328125 & 0,265625 & 0,125 \\
\cline { 3 - 7 } 0,9 & & SSIM & 0,86089 & 0,291971 & 0,429574 & 0,733842 \\
\cline { 3 - 7 } Alfa & & PSNR & 53,67941 & 56,86462 & 56,50376 & 56,07586 \\
0,01 & \multirow{2}{*}{0,1} & BER & 0,050781 & 0,375 & 0,265625 & 0,125 \\
\cline { 3 - 7 } & & SSIM & 0,887421 & 0,199524 & 0,425421 & 0,733842 \\
\cline { 3 - 7 } & & PSNR & 53,67941 & 56,86462 & 56,50376 & 56,07586 \\
\hline
\end{tabular}

Berdasarkan Tabel 13, watermark dapat bertahan pada serangan penambahan noise salt and pepper. Penerapan CS menyebabkan watermark lebih rentan terhadap serangan ini. Hal ini disebabkan oleh perubahan nilai yang cukup drastis pada bit-bit tertentu yang menimbulkan kesalahan pada proses extraction watermark dengan penggunaan CS.

\subsubsection{Ketahanan Watermark terhadap Serangan JPEG Compression}

Joint Photograohic Experts Group Compression atau yang banyak disebut JPEG Compression merupakan metode kompresi terhadap suatu gambar digital. Kompresi ini bersifat lossy compression dan dapat disesuaikan derajat kompresinya. 
Hafizhana, dkk

Tabel 14. Hasil Pengujian Serangan JPEG Compression

\begin{tabular}{|c|c|c|c|c|c|c|}
\hline Status & JPEG Comp. Ratio & Value & Tanpa CS & CS 20\% & CS $40 \%$ & CS $60 \%$ \\
\hline \multirow{12}{*}{$\begin{array}{c}\text { Resolusi Host } \\
256 \times 256 \\
\text { Faktor Sisip } \\
0,9 \\
\text { Alfa } \\
0,01\end{array}$} & \multirow{3}{*}{$25 \%$} & BER & 0,40625 & 0,34375 & 0,34375 & 0,34375 \\
\hline & & SSIM & 0,049661 & 0,213355 & 0,213355 & 0,213355 \\
\hline & & PSNR & 53,67941 & 56,86462 & 56,50376 & 56,07586 \\
\hline & \multirow{3}{*}{$50 \%$} & BER & 0,40625 & 0,328125 & 0,328125 & 0,328125 \\
\hline & & SSIM & 0,054316 & 0,244827 & 0,244827 & 0,244827 \\
\hline & & PSNR & 53,67941 & 56,86462 & 56,50376 & 56,07586 \\
\hline & \multirow{3}{*}{$75 \%$} & BER & 0,394531 & 0,3125 & 0,3125 & 0,28125 \\
\hline & & SSIM & 0,067678 & 0,283393 & 0,283393 & 0,354746 \\
\hline & & PSNR & 53,67941 & 56,86462 & 56,50376 & 56,07586 \\
\hline & \multirow{3}{*}{$100 \%$} & BER & 0,046875 & 0,359375 & 0,265625 & 0,109375 \\
\hline & & SSIM & 0,896229 & 0,227546 & 0,422805 & 0,764557 \\
\hline & & PSNR & 53,67941 & 56,86462 & 56,50376 & 56,07586 \\
\hline
\end{tabular}

Dapat diamati melalui Tabel 14, watermark hanya dapat bertahan dengan baik pada kompresi JPEG dengan rasio $100 \%$. Penerapan CS pada watermark, menyebabkan peningkatan kerentanan watermark terhadap serangan kompresi JPEG 100\%. Penggunaan CS rasio $60 \%$ dapat bertahan cukup baik pada kompresi JPEG 100\%. Namun, seperti terlihat pada Tabel 14, penggunaan CS meningkatkan ketahanan watermark terhadap serangan kompresi JPEG dengan rasio $25 \%, 50 \%$ dan $75 \%$. Hasil pengujian serangan JPEG compression dapat dilihat pada Tabel 14.

\subsection{Mean Opinion Score (MOS)}

Mean Opinion Score (MOS) merupakan kumpulan penilaian subjektif dari sejumlah responden yang dilakukan untuk mendukung hasil penelitian ini. Penilaian diambil melalui proses pengamatan responden, berdasarkan indra penglihatan manusia atau Human Visual System (HVS), dalam membandingkan antara gambar asli dengan gambar yang telah disisipkan watermark. Hasil rekapitulasi kuisioner mean opinion score dapat dilihat pada Tabel 15.

Tabel 15. Hasil Rekapitulasi Kusioner Mean Opinion Score

\begin{tabular}{|c|c|c|c|c|}
\hline Perbandingan & $\mathbf{1}$ & $\mathbf{2}$ & $\mathbf{3}$ & $\mathbf{4}$ \\
\hline Citra Host & $256 \times 256$ & $512 \times 512$ & $1.024 \times 1.024$ & $2.048 \times 2.048$ \\
\hline MOS & 3,884615 & 4,102564 & 4,102564 & 4,076923 \\
\hline
\end{tabular}

Setelah dilakukan rekapitulasi data, didapatkan sebanyak 78 responden yang telah berpartisipasi dalam pengambilan nilai perbandingan dengan menggunakan kuesioner yang telah dibuat. Berdasarkan hasil dari Tabel 15, dapat di ketahui bahwa hasil proses watermarking dapat dinilai baik menurut indra penglihatan manusia dengan nilai MOS ratarata 4 atau baik.

\section{KESIMPULAN}

Setelah dilakukan pengujian dan analisis pada skema watermarking yang telah dirancang, proses image watermarking menggunakan metode Statistical Mean Manipulation (SMM) berbasis Stationary Wavelet Transform (SWT) dengan penerapan Compressive Senssing (CS) algoritma Orthogonal Matching Pursuit dapat direalisasikan dan dapat diimplementasikan dengan cukup baik. Hal ini dapat dilihat berdasarkan nilai PSNR membaik hingga 3,5 dB pada CS dengan resolusi $8 \times 8$ pixel. Penerapan serangan terhadap host yang telah disisipkan watermark, tanpa penggunaan Compressive Sensing, menunjukkan bahwa watermark dapat bertahan terhadap serangan Salt and Pepper (SSIM dengan kisaran 0,86089-0,912869), Scaling 150\% (SSIM = 0,82555), dan JPEG 100\% (SSIM = 0,896229).

$$
\text { ELKOMIKA - } 56
$$


Image Watermarking pada Citra Medis Menggunakan Compressive Sensing berbasis Stationary Wavelet Transform

\section{DAFTAR RUJUKAN}

Bash, A. A., \& Kayhan, S. K. (2015). Watermarked Compressive Sensing Measurements Reconstructed by the Greedy Algorithms. International Journal of Computer Theory and Engineering, $7(3), 219-222$.

Candes, E. J., \& Wakin, B. M. (2008). An Introduction To Compressive Sampling. IEEE Signal Processing, 21-30.

Cox, I., Miller, M., Bloom, J., Fridrich, J., \& Kalker, T. (2008). Digital Watermarking and Steganography Second Edition. Hawthorne: Elsevier inc.

Jones, R. (2013, July 16). Answer to headache/seizure. Retrieved from EM REMS: https://emrems.com/category/mri/

Kumar, S. B., \& Ramashri, D. (2012). Robust SWT SVD Based Digital Image Watermarking Technique. International Journal of Computer Science Information and Engineering Technologies ISSN 2277-4408, 1-4.

Li, X., \& Yu, H. H. (2000). Transparent and Robust Audio Data Hiding in Cepstrum Domain. International Conference on Multimedia and Expo. ICME2000. (pp. 397-400). New York: IEEE.

Pangestu, A. (2017). Analisis Image Watermarking Menggunakan Compressive Sensing Algoritma Orthogonal Matching Pursuit dengan Pendekatan Berbasis Discrete Cosine Transform Menggunakan Singular Value Decomposition. Bandung: Telkom University.

Purohit, N., Chennakrishna, M., \& Manikantan, K. (2017). Novel Digital Image Watermarking in SWT+SVD Domain. Proceedings of the International Conference on Signal, Networks, Computing, and System Volume 1 (pp. 12-23). New Delhi: Springer India.

Ward, D. L. (2018). Redundant Discrete Wavelet Transform Based Super-Sesolution Using Sub-Pixel Image registration. Ohio: Air Force Institute of Technology.

Wen, X., Ding, X., Li, J., Gao, L., \& Sun, H. (2009). An Audio Watermarking Algorithm Based on Fast Fourier Transform. International Conference on Information Management, Innovation Management and Industrial Engineering (pp. 0-3). Xi'an: IEEE.

Zain, J. M., \& Clarke, M. (2005). Security In Telemedicine: Issues In Watermarking Medical Images. 3rd International Conference : Sciences of Electronic, Technologies of Information and Telecommunication. Sousse: IEEE.

Zhang, Y., Dong, Z., Wu, L., Wang, S., \& Zhou, Z. (2010). Feature extraction of brain MRI by stationary wavelet transform. International Conference on Biomedical Engineering and Computer Science, ICBECS 2010, 115-132.

ELKOMIKA - 57 